\title{
Benthic Community of the Sungai Pulai Seagrass Bed, Malaysia
}

\author{
Zaleha, K. ${ }^{1}$, Farah Diyana, M. F. ${ }^{1}$, Amira Suhaili, R. ${ }^{2}$, and Amirudin, A. ${ }^{3}$ \\ ${ }^{1}$ Institute of Tropical Aquaculture, ${ }^{2}$ Department of Marine Science, ${ }^{3}$ Department of Biology, \\ Universiti Malaysia Terengganu, 21030, Kuala Terengganu, Malaysia. \\ *farahdotcom85@yahoo.co.uk and zaleha@umt.edu.my (corresponding author) \\ Received in $3^{\text {rd }}$ March 2008, accepted in revised form $14^{\text {th }}$ July 2009.
}

\begin{abstract}
An ecological survey was carried out to investigate the benthos community structure based on density and diversity of the meiobenthos and macrobenthos communities inhabiting the seagrass bed and to investigate their relationship with environmental factors at Sungai Pulai estuary, Johor. A PVC hand corer was used to collect sediment samples from the $3^{\text {rd }}$ to the $5^{\text {th }}$ of December 2006 during the lowest tide. Three

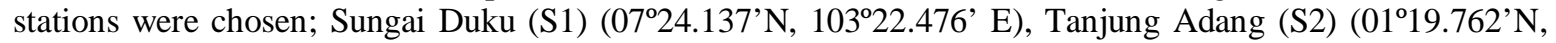
$103^{\circ} 33.894^{\prime}$ E) and Merambong (S3) (01 $\left.{ }^{\circ} 20.094^{\prime} \mathrm{N} 103^{\circ} 35.982^{\prime} \mathrm{E}\right)$. The highest density of meiobenthos was found at S2 followed by S3 and S1. The macrobenthos density was found to be greatest at S3 followed by S2 and S1. S2 had the highest diversity index with a value of 1.69 and 2.06 for meiobenthos and macrobenthos respectively. The statistical analysis demonstrated a significant difference existed between the benthic assemblages of the three stations. The differences in environmental parameters might be responsible for the assemblages of benthic community between stations.
\end{abstract}

\begin{abstract}
ABSTRAK Pemantauan ekologi telah dilakukan untuk menyiasat komuniti struktur bentos berdasarkan kepadatan dan kekayaan komuniti meiobentos dan makrobentos yang hidup di padang rumput laut dan juga bagi menyiasat perhubungan mereka dengan faktor-faktor persekitaran di muara Sungai Pulai, Johor. Tiub pengorek PVC digunakan untuk mengambil sampel sedimen bermula dari 3 hingga 5 Disember 2006 semasa air surut penuh. Tiga stesen penyampelan iaitu; Sungai Duku (S1) $\left(07^{\circ} 24.137^{\prime} \mathrm{N}, 1^{\circ} 3^{\circ} 22.476^{\prime}\right.$ ' E), Tanjung Adang (S2) $\left(01^{\circ} 19.762^{\prime} \mathrm{N}, 103^{\circ} 33.894^{\prime}\right.$ E) dan Merambong (S3)(01⒛094'N 103³5.982'E). Hasil kajian didapati jumlah kepadatan meiobentos tertinggi ditemui di S2, kemudian di S3 dan S1. Manakala jumlah kepadatan makrobentos tertinggi ditemui di S3, kemudian di S2 dan S1. S2 didapati mempunyai indeks kekayaan tertinggi dengan nilai 1.69 bagi meiobentos dan 2.06 bagi nilai makrobentos. Analisis statistik menunjukkan terdapat perbezaan bererti wujud antara pengumpulan bentik di tiga stesen. Perbezaan parameter persekitaran berkemungkinan bertanggungjawab dalam perbezaan pengumpulan komuniti bentik antara stesen.
\end{abstract}

(Keywords: Meiobenthos, macrobenthos, density, diversity, seagrass bed, Sungai Pulai estuary.)

\section{INTRODUCTION}

The term benthos is derived from the Greek word 'vanthos' meaning depth and refers to the communities of organism living in the benthic zone of an aquatic ecosystem [1] [2]. Benthos can be categorized according to their size. Generally, macrobenthos is the entire organism retained on a sieve with a mesh size of $500 \mu \mathrm{m}$, and ranging to $1000 \mu \mathrm{m}$ in size [3]. Meiobenthos refers to meiofauna that live in the sediments [4]. The size range of meiobenthos is between $63 \mu \mathrm{m}$ and 500 $\mu \mathrm{m}$ [5]. Meiobenthos is also categorized based on the separation method as all metazoans are retained on a sieve of $42 \mu \mathrm{m}$ [6]. The distribution of benthos is strongly influenced by abiotic factors such as sediment size, sediment organic content, sediment nutrient content, water quality, current velocity and depth of water [7]. As these benthic fauna are predominantly sedentary, the measurement of their community structure changes in combination with appropriate 
environmental variables is widely used to detect any marine environment disturbance caused by anthropogenic sources [8]. Meiobenthos organisms are the most sensitive assemblages as they have short lifespan spent entirely in the sediment and lack larval dispersion. Nematodes for example, have been used as indicators of organic disturbance because of their ubiquity, high densities and high taxonomic diversity [9]. Macrobenthos serve as food for higher level organisms such as shrimp and fish [10]. According to [11], macrobenthos are the main food source for most aquatic organism such as demersal fish. They are also subjected to the complex food web and nutrient recycling in marine ecosystem.

The meadows of seagrasses constitute areas of high productivity, providing feeding and breeding grounds for a diversity of fauna [13], and generally support important human activities. The dense area of seagrass that provide the most stable substrate for benthic organisms, which is highly sheltered from wave activity, and is a good habitat for the diversity and density of nematodes [13]. Besides shelter, seagrass beds offer a rich source of detritus food, due to a plentiful food supply, large communities of infaunal detritivores associate within this area and the mud between the rhizomes abounds in polychaetes, bivalves, snails and amphipods [14]. Due to their importance in coastal ecosystems worldwide, seagrasses and associated fauna have been the subject of a large number of studies [15][16]. [17] in their study in India reported that the average densities range between 634 and 6251 ind. $/ 10 \mathrm{~cm}^{2}$ and this is among the highest benthic densities reported for tropical seagrass beds.

This study was conducted in the seagrass beds of Sungai Pulai estuary, Johor which is a massive seagrass bed the size of several football fields [18]. This study was conducted in order to investigate the community structure of benthic fauna by analyzing their density and diversity in the seagrass area. Research on seagrass and its ecosystem has been done worldwide and is well documented in temperate countries. However, research on benthic fauna communities inhabiting seagrass meadow and their abundances has received little atention in Malaysia [20]. This study will provide a detailed baseline of the composition, density and diversity of the benthic community in the seagrass beds at Sungai Pulai estuary, essential for long term monitoring as well as providing information needed to answer fundamental questions concerning benthic fauna on seagrass beds.

\section{MATERIALS AND METHOD}

\section{Study sites}

Sampling was conducted in the seagrass beds of Sungai Pulai estuary, Johor from the $3^{\text {rd }}$ to the $5^{\text {th }}$ of December 2006 during the lowest tide. The estuary had extensive intertidal seagrass beds colonizing the shallow depths of 2-3 metre of both muddy banks from the lower reaches up to upper parts of the middle reach near Sungai Jeram [18]. The subtidal seagrass shoals in Sungai Pulai are generally multi-species and dominated by four species of seagrass, which are Enhalus acoroides, Halophila ovalis, Halophila spinulosa and Syringodium isoetifolium [18]. Three sampling stations (Table 2.1) were selected within the estuary - Sungai Duku (S1), Tangjung Pelepas (S2) and Merambong (S3).

Table 2.1. GPS reading of the sampling stations

\begin{tabular}{lcc}
\hline Stations & Latitude (N) & Longitude (E) \\
\hline $\begin{array}{l}\text { Sungai Duku } \\
\text { (S1) }\end{array}$ & $07^{\circ} 24.137^{\prime}$, & $103^{\circ} 22.476^{\prime}$ \\
$\begin{array}{l}\text { Tanjung } \\
\text { Adang (S2) }\end{array}$ & $01^{\circ} 19.762^{\prime}$ & $103^{\circ} 33.894^{\prime}$ \\
$\begin{array}{l}\text { Merambong } \\
\text { (S3) }\end{array}$ & $01^{\circ} 20.094^{\prime}$ & $103^{\circ} 35.982^{\prime}$ \\
\hline
\end{tabular}

\section{Sampling strategy}

At each station, the sediment samples were collected within the three quadrates frame, $0.5 \mathrm{~m}$ x $0.5 \mathrm{~m}$ along three transects with a $12 \mathrm{~m}$ length starting from the bank to the upper site of the area. Situated on transects, the distances of the quadrates were approximately $5 \mathrm{~m}$ from each other. In each quadrate frame, triplicate of sediment samples were collected using a PVC hand core with $2 \mathrm{~cm}$ inner diameter. Meiobenthos samples were obtained by inserting the hand core to a $10 \mathrm{~cm}$ depth [19] of the uppermost layer of the bottom sediment. Meanwhile the PVC hand core with $15 \mathrm{~cm}$ diameter was inserted into the 
sediment down to a depth of $10 \mathrm{~cm}$ to collect the macrobenthos samples. Core samples were then transferred into labeled plastic bags and immediately fixed using $10 \%$ formalin solution [21]. This sampling design yielded a total of 81 samples. Additional sediment samples were collected at each sampling station and brought back to the laboratory for the particle size analysis. Water parameters at the sampling area such as temperature, salinity, dissolved oxygen concentration, $\mathrm{pH}$, and conductivity were measured in situ using YSI 556 multi-parameter.

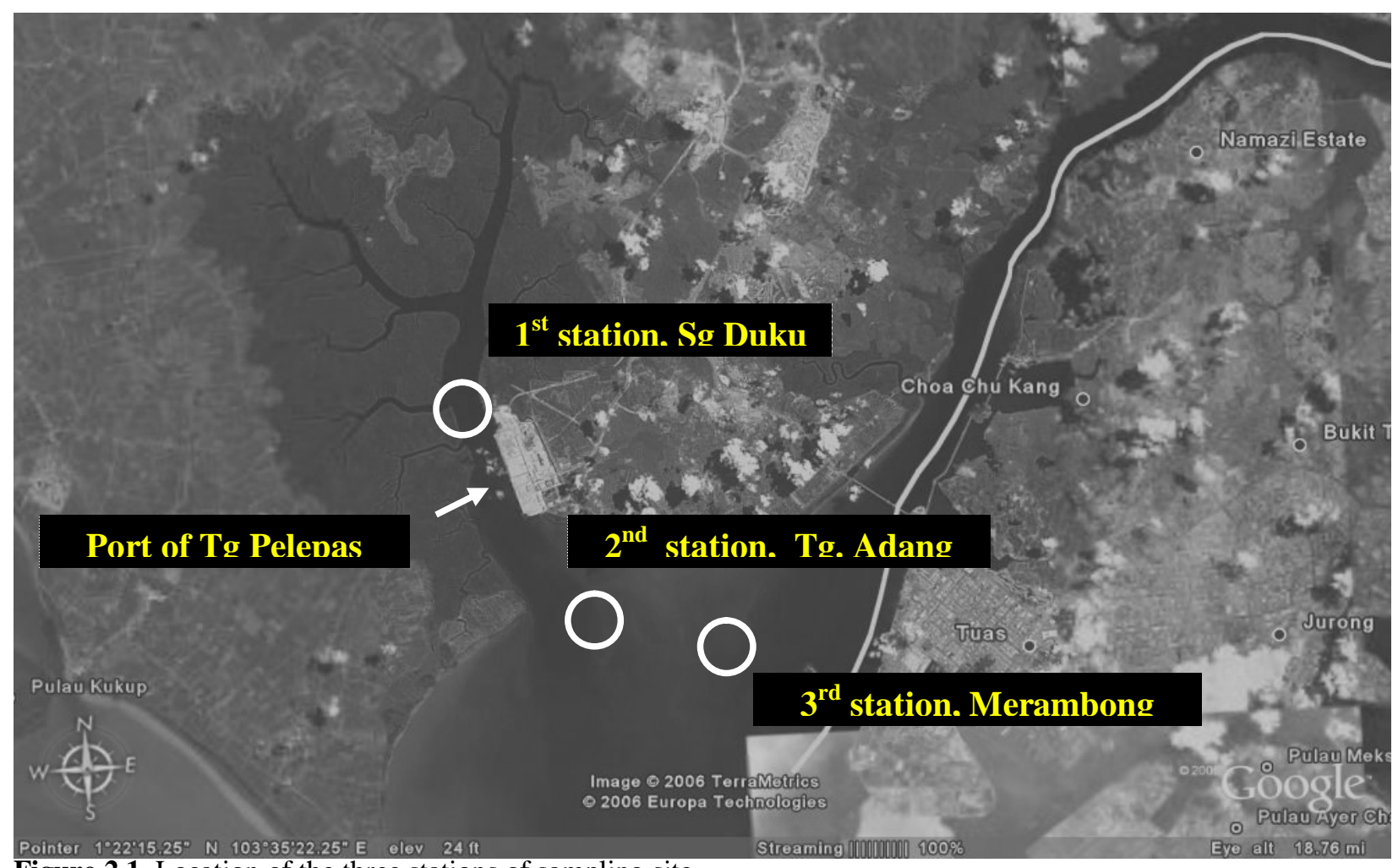

Figure 2.1. Location of the three stations of sampling site

Available from: www.googlearth.com.my

\section{Sample processing Meiobenthos}

In the laboratory, sample decantation [22] was conducted for each sample. Sediment samples was placed in a glass cylinder, filled with water, inverted and allowed to settle for 15 seconds. The supernatant was then sieved onto a $63 \mu \mathrm{m}$ sieve. This procedure was repeated three times for each sample. The materials retained on the $63 \mu \mathrm{m}$ sieve were preserved in labeled bottles containing 5\% neutralized formalin mixed with Rose Bengal stain [19]. The meiobenthos were sorted under a stereomicroscope [23]. The number of specimens in each taxa were counted photographed with a compound microscope.

\section{Macrobenthos}

Each sediment sample was sieved through a 500 $\mu \mathrm{m}$ sieve and the macrobenthos retained on the sieve were collected using a pair of smooth forceps. The samples collected were then placed in the labeled bottles containing 10\% neutralized formalin mixed with Rose Bengal stain. The macrobenthos were identified to the lowest possible taxa based on [24], [25], and [26] under a dissecting microscope. The number of specimens in each taxa was counted and photographed. The polychaetes samples were identified to family level following [24].

\section{Particle size analysis}

For the analyses of sediment, $100 \mathrm{~g}$ of oven-dried sediment from each station was sieved using a 
series of $250 \mu \mathrm{m}, 150 \mu \mathrm{m}, 125 \mu \mathrm{m}, 90 \mu \mathrm{m}, 63 \mu \mathrm{m}$ mesh opening to give a Wenworth grade classification of particle size [27]. This dry sieving was only been carried out for the sediment from Tanjung Adang (S2) and Merambong (S3). However, the particle mean size of Sungai Duku (S1) could not be determined because the Malven Master Seizer 2000 for particle size analysis was not functioning. Data was then only based on observations taken during field work.

\section{Data analysis}

The density of meiobenthos and macrobenthos were estimated as number of individuals $(\mathrm{N})$ per unit area $\left(10 \mathrm{~cm}^{2}\right)$ and $(10 \mathrm{~m} 2)$ respectively. The meiobenthos and macrobenthos community structure at the three stations (Sungai Duku (S1), Tanjung Adang (S2), and Merambong (S3) were determined using univariate and multivariate analysis. The univariate analysis included the Shannon-Wiener diversity $\left(\mathrm{H}^{\prime}\right)$ index, Species richness index (d) as the total number of taxa and Pielou evenness ( $\mathbf{J}$ ') index were estimated. The data was analyzed using PRIMER (Plymouth Routines in Multivariate Ecological Research) software package [28]. For multivariate analysis, the Bray-Curtis similarity measure was used to estimate similarities in benthic community structure between the different stations. Nonmetric multi-dimensional scaling ordination
(MDS) using the Bray-Curtis similarity measure was applied to square root transformation data. This was to build a graphical representation of the samples pattern and the rank of the similarity between the samples. One-way ANOSIM was performed to determine if there were significant differences between groups of meiobenthic and macrobenthic samples.

\section{RESULTS}

\section{Environmental parameters}

The variation in water temperature, salinity and $\mathrm{pH}$ was insignificant between sampling stations (Table 3.1). The mean temperature was lowest in Sungai Duku (S1) $\left(29.31^{\circ} \mathrm{C}\right)$ and highest in Merambong ( $\mathrm{S} 3)\left(30.02^{\circ} \mathrm{C}\right)$. The highest mean $\mathrm{pH}$ was in Merambong (S3) at 8.64, followed by Tanjung Adang (S2) with a pH of 7.95. Located at the upper stream, Sungai Duku (S1) had the lowest mean salinity (28.87 psu) followed by Tanjung Adang (S2) (30.95 psu) which is located down stream. The mean salinity in Merambong (S3) was the highest at $31.21 \mathrm{psu}$ as it is located in close proximity to the sea. Dissolved oxygen varied among stations. The highest mean DO $(\mathrm{mg} / \mathrm{L})$ was recorded in Merambong (S3), which was $7.64 \mathrm{mg} / \mathrm{L}$, and the lowest mean was 2.64 $\mathrm{mg} / \mathrm{L}$ in Tanjung Adang (S2), while in Sungai Duku (S1), the DO (mg/L) was $4.19 \mathrm{mg} / \mathrm{L}$.

Table 3.1. Physico-chemical parameters measured in the three stations of the Sungai Pulai estuary.

\begin{tabular}{lccc}
\hline Parameters & Sungai Duku (S1) & Tanjung Adang (S2) & Merambong (S3) \\
\hline Temperature $\left({ }^{\circ} \mathrm{C}\right)$ & $29.31 \pm 0.17$ & $29.46 \pm 0.16$ & $30.02 \pm 0.19$ \\
$\mathrm{pH}$ & $7.540 \pm 0.52$ & $7.950 \pm 0.72$ & $8.640 \pm 0.80$ \\
Salinity $(\mathrm{psu})$ & $28.87 \pm 0.98$ & $30.95 \pm 0.55$ & $31.21 \pm 0.80$ \\
Dissolved oxygen $(\mathrm{mg} / \mathrm{L})$ & $4.190 \pm 0.58$ & $2.640 \pm 0.43$ & $7.640 \pm 0.70$ \\
\hline
\end{tabular}

Sedimentary parameters

Table 3.2. Mean particle size of sediments in sampling stations of the Sungai Pulai estuary

\begin{tabular}{lcc}
\hline Station & Tanjung Adang (S2) & Merambong (S3) \\
\hline Parameter & Phi & Phi \\
Mean (x) & 2.81 & 2.847 \\
Sorting & 1.10 & 1.03 \\
Skewness & -0.22 & -0.33 \\
Kurtosis & 0.79 & 0.91 \\
\hline
\end{tabular}


The difference in particle mean size (Table 3.2) in Tanjung Adang (S2) and Merambong (S3) was insignificant with values of 2.81 phi and 2.85 phi respectively. The sorting coefficient was 1.1 in Tanjung Adang (S2) and 1.03 in Merambong (S3) could be classified as fine sand, mostly well sorted. Based on examination during the field sampling, the sediment type of Sungai Duku (S1) can be classified as soft muddy. Percentage of mud was more than $90 \%$ and sand particles retained on 63 $\mu \mathrm{m}$ sieve was less than $5 \%$.

\section{Density of benthos Meiobenthos}

A total of 13 meiobenthic taxa were found in the seagrass beds of the Sungai Pulai estuary, Johor within the three sampling sites. The taxa found were Nematoda, Harpacticoida, Calanoida,
Cyclopoida, Ostrocoda, Polychaeta, Oligochaeta, Isopoda, Amphipoda, Gastropoda, Bivalvia, Cumacea and Tanaidacea. In all sampling stations, the dominant meiobenthos was nematodes (Table 3.3 ) with a mean density ranging from 45 to 50 inds. $10 \mathrm{~cm}^{-2}$ in Sungai Duku (S1), 58 to 152 inds $10 \mathrm{~cm}^{-2}$ in Tanjung Adang (S2), and 111 to 174 inds $10 \mathrm{~cm}^{-2}$ in Merambong (S3). Harpacticoid copepods were the second dominant group in Sungai Duku (S1) and Merambong (S3) with a mean density ranging from 17 to 22 inds $10 \mathrm{~cm}^{-2}$ and 75 to 94 inds $10 \mathrm{~cm}^{-2}$ respectively. The total mean density of meiobenthos found in the Sungai Duku (S1) was low, ranging from 68 to 75 inds 10 $\mathrm{cm}^{-2}$. In Tanjung Adang (S2), the density ranged from 317 to 486 inds $10 \mathrm{~cm}^{-2}$ and had the highest mean density of total meiobenthos in the study area.

Table 3.3. Mean total density (ind. $\left./ 10 \mathrm{~cm}^{2}\right)$ of main meiobenthic taxa along transect $(1,2$, and 3$)$ in three stations (S1, S2 and S3) in seagrass beds of the Sungai Pulai estuary. (Note: Trans = Transect)

\begin{tabular}{|c|c|c|c|c|c|c|c|c|c|}
\hline & \multicolumn{3}{|c|}{ Station1 } & \multicolumn{3}{|c|}{ Station 2} & \multicolumn{3}{|c|}{ Station 3} \\
\hline & Trans 1 & Trans 2 & Trans 3 & Trans 1 & Trans 2 & Trans 3 & Trans 1 & Trans 2 & Trans 3 \\
\hline Nematoda & $50 \pm 33.2$ & $45 \pm 39.4$ & $45 \pm 40.6$ & $152 \pm 125$ & $102 \pm 87.3$ & $58 \pm 56.4$ & $152 \pm 125$ & $111 \pm 68$ & $174 \pm 145$ \\
\hline Harpacticoid Cop. & $20 \pm 12.2$ & $22 \pm 15.5$ & $17 \pm 11.5$ & $58 \pm 44.3$ & $64 \pm 32.8$ & $36 \pm 22.2$ & $94 \pm 61.7$ & $81 \pm 78.4$ & $75 \pm 45.2$ \\
\hline Calanoid Copepod & 0 & $4.0 \pm 3.8$ & 0 & $96 \pm 94.3$ & $55 \pm 53.8$ & $131 \pm 129$ & $3.0 \pm 2.8$ & 0 & $2.0 \pm 1.6$ \\
\hline Copepod nauplii & $1.0 \pm 1.7$ & $2.0 \pm 1.4$ & $2.0 \pm 1.4$ & $120 \pm 118$ & $59 \pm 34.4$ & $75 \pm 72.8$ & $17 \pm 18.5$ & $21 \pm 18.5$ & $14 \pm 15.3$ \\
\hline Copepodite & 0 & 0 & 0 & $31 \pm 31.7$ & $15 \pm 13.5$ & $30 \pm 29.2$ & $4.0 \pm 3.8$ & $2.0 \pm 2.5$ & $7.0 \pm 6.3$ \\
\hline Ostracoda & $3.0 \pm 2.2$ & $2.0 \pm 2.4$ & $3.0 \pm 2.8$ & $19 \pm 18.8$ & $11 \pm 10.6$ & $9.0 \pm 9.4$ & $6.0 \pm 4.7$ & $4.0 \pm 3.2$ & $12 \pm 11.8$ \\
\hline Gastropod juvenile & $1 \pm 1.66$ & $1 \pm 0.45$ & $1 \pm 1.34$ & $2.0 \pm 2.4$ & $2 \pm 1.86$ & $4 \pm 4.44$ & 0 & $1.0 \pm 0.35$ & $2.0 \pm 2.28$ \\
\hline Bivalvia juvenile & 0 & 0 & 0 & $8 \pm 8.34$ & $9 \pm 7.79$ & $9 \pm 9.49$ & $1 \pm 2.7$ & $2.0 \pm 3.2$ & $2.0 \pm 1.27$ \\
\hline Total numbers & 75 & 76 & 68 & 486 & 317 & 352 & 277 & 222 & 288 \\
\hline
\end{tabular}

Density distribution of meiobenthos in the study area is summarized in Figure 3.1. Sungai Duku (S1) is a mangrove forest where the quadrates were placed along transects starting from the riverbank to the ground in close proximity to the mangrove tree line. All the first quadrates (Q1) were more exposed to the freshwater inflow had the lowest mean total density. Meanwhile the third quadrates (Q3) located far from the incoming waves and tidal currents supported a higher number of meiobenthos. Merambong (S3) also showed the same trend as in Sungai Duku (S1) with the mean total densities of meiobenthos slightly increasing with increasing distance of the quadrate from the bank. However, in Tanjung Adang (S2), the mean total densities of meiobenthos showed fluctuations between quadrates for each transect and there were no significant pattern as shown in Sungai Duku (S1) and Merambong (S3). The mean total densities of meiobenthos varied between quadrates (Figure 3.1). 
Malaysian Journal of Science 28 (2): 143- 159 (2009)

(a)

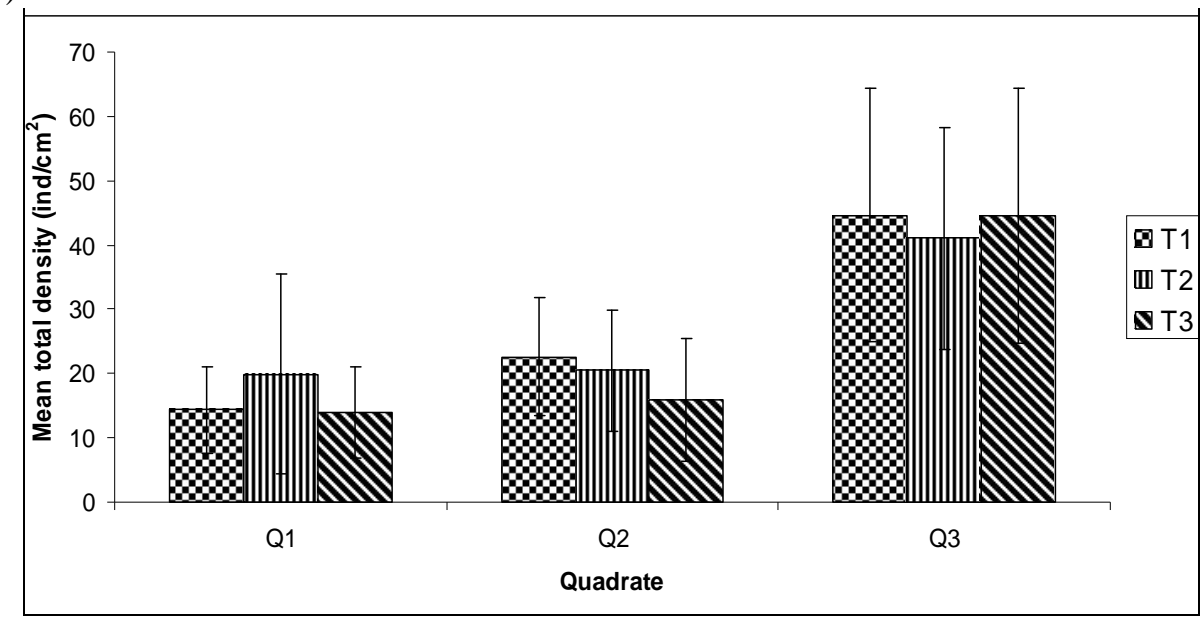

(b)

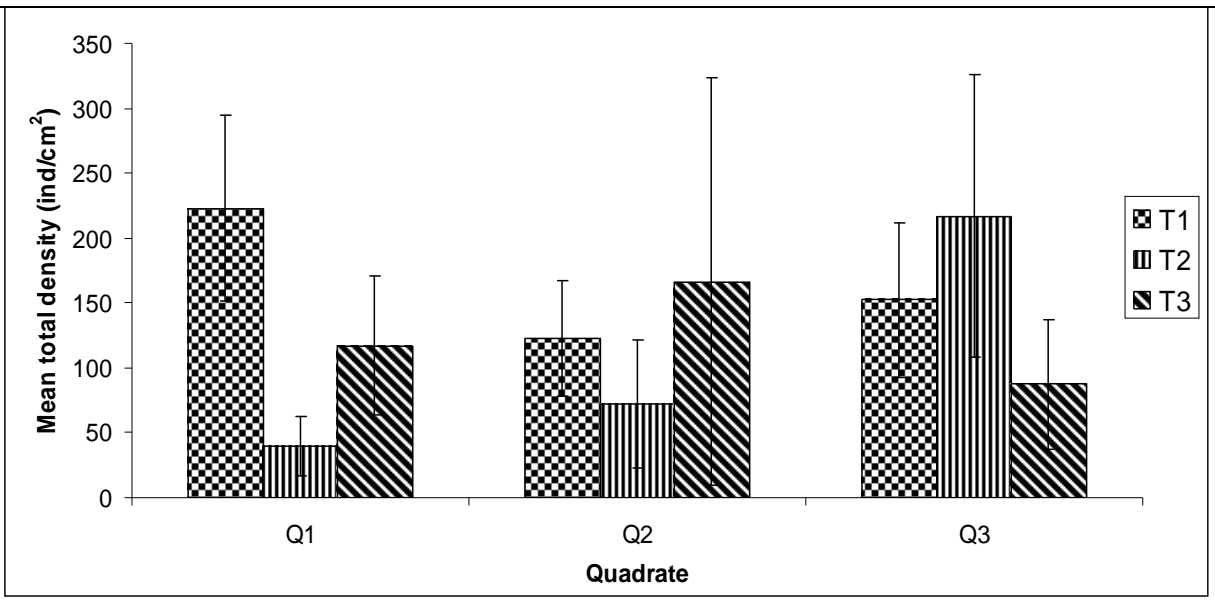

(c)

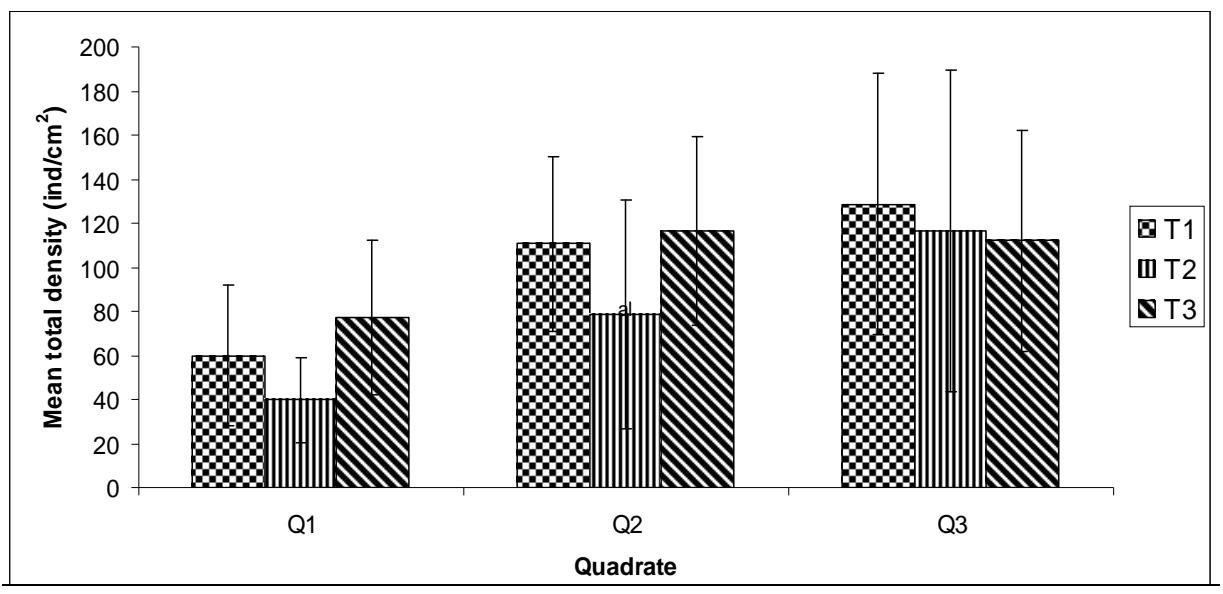

Figure 3.1. Mean density (ind./10 $\mathrm{cm}^{2}$ ) of meiobenthos in (a) Sungai Duku (S1), (b) Tanjung Adang (S2), and (c) Merambong (S3). Note: $\mathrm{T}=$ transect 


\section{Macrobenthos}

Ten macrobenthic taxa were found in the seagrass beds of Sungai Pulai estuary, Johor within the three sampling sites (Table 3.4). Polychaeta, Bivalvia, Gastropoda and Crustacea were the common groups recorded. Others included Oligochaeta, Amphipoda, Euphausiidae, Isopoda, Decapoda, Sipuncula and Holothuroidea. Polychaetes were abundant in Merambong (S3), with densities ranging from 472 to $1054 \mathrm{ind} / \mathrm{m}^{2}$. The mean total density of macrobenthos found in the Sungai Duku (S1) was low, ranging from from 275 to $450 \mathrm{ind} / \mathrm{m}^{2}$. In Tanjung Adang (S2), the total mean density of macrobenthos ranged from 703 to $744 \mathrm{ind} / \mathrm{m}^{2}$ and in Merambong (S3), the density ranged from 1044 to $2742 \mathrm{ind} / \mathrm{m}^{2}$.
In Sungai Duku (Figure 3.4), the mean total density of macrobenthos increased from the first quadrate $(\mathrm{Q} 1)$ to the third quadrate $(\mathrm{Q} 3)$ in the first transect (T1) indicating more macrobenthos aggregated towards the quadrate located in higher ground when compared to quadrates located at the edge of the water. In Tanjung Adang (S2), the macrobenthos within this location did not show any distribution pattern. In Merambong (S3), the mean density of macrobenthos also showed fluctuations between quadrates for the first (T1) and third (T3) transects. However, the density of macrobenthos in the second transect (T2) demonstrated an increased pattern moving from the first to the third quadrate. The results showed that there was no distinct relationship between the mean densities of macrobenthos with the location of quadrates.

Table 3.4. Mean total density (ind $/ \mathrm{m}^{2}$ ) of main macrobenthos taxa along transect $(1,2$, and 3 ) in three stations (S1, S2 and S3) in seagrass beds of the Sungai Pulai estuary. (Note: Trans = Transect)

\begin{tabular}{lccccccccc}
\hline & \multicolumn{3}{c}{ Station1 } & \multicolumn{5}{c}{ Station 2 } & \multicolumn{4}{c}{ Station 3 } \\
& Trans 1 & Trans 2 & Trans 3 & Trans 1 & Trans 2 & Trans 3 & Trans 1 & Trans 2 & Trans 3 \\
\cline { 2 - 10 } & & & & & & & & \\
Polychaeta & $117 \pm 73.9$ & $54 \pm 18.8$ & $76 \pm 88.6$ & $276 \pm 104$ & $330 \pm 143$ & $217 \pm 67.8$ & $1054 \pm 435$ & $472 \pm 324$ & $697 \pm 352.2$ \\
Oligochaeta & $65 \pm 56.5$ & $22 \pm 37.6$ & $24 \pm 21.2$ & 0 & 0 & 0 & 0 & 0 & 0 \\
Gastropoda & $87 \pm 54.7$ & $72 \pm 34.8$ & $96 \pm 34.7$ & $90 \pm 26.3$ & $58 \pm 26.8$ & $47 \pm 55.6$ & $1210 \pm 489$ & $342 \pm 166$ & $914 \pm 181$ \\
Bivalvia & $77 \pm 66.6$ & $22 \pm 18.8$ & $40 \pm 43.5$ & $41 \pm 13.7$ & $40 \pm 43.5$ & $136 \pm 127$ & $180 \pm 42.3$ & $136 \pm 44.6$ & $131 \pm 75.4$ \\
Amphipoda & $72 \pm 71.6$ & $83 \pm 71.9$ & $54 \pm 49.8$ & $171 \pm 98.1$ & $138 \pm 84.5$ & $147 \pm 114$ & $91 \pm 37.3$ & $40 \pm 43.2$ & $43 \pm 18.8$ \\
Euphausiids & 0 & 0 & 0 & $22 \pm 37.6$ & $50 \pm 66.3$ & $33 \pm 55.2$ & $22 \pm 18.8$ & 0 & 0 \\
Isopoda & $22 \pm 18.8$ & 0 & 0 & $71 \pm 123.4$ & $54 \pm 45.2$ & $65 \pm 70.3$ & $11 \pm 18.8$ & 0 & $33 \pm 32.4$ \\
Decapoda & 0 & 0 & $11 \pm 15.5$ & 0 & 0 & $11 \pm 18.8$ & 0 & 0 & 0 \\
Sipuncula & 0 & 0 & 0 & $19 \pm 21.1$ & $22 \pm 18.8$ & $22 \pm 18.8$ & $69 \pm 43.3$ & $11 \pm 18.8$ & $22 \pm 31.3$ \\
Holothuroidea & 0 & 0 & 0 & $11 \pm 11.5$ & 0 & $43 \pm 56.5$ & 0 & 0 & 0 \\
Others & $11 \pm 18.8$ & $22 \pm 30.6$ & 0 & $22 \pm 18.8$ & $11 \pm 18.8$ & $22 \pm 31.2$ & $105 \pm 60.6$ & $43 \pm 45.3$ & $83 \pm 16.7$ \\
& & & & & & & & & \\
Total Numbers & 450 & 275 & 302 & 723 & 703 & 744 & 2742 & 1044 & 1923 \\
\hline
\end{tabular}


Malaysian Journal of Science 28 (2): 143- 159 (2009)

(a)

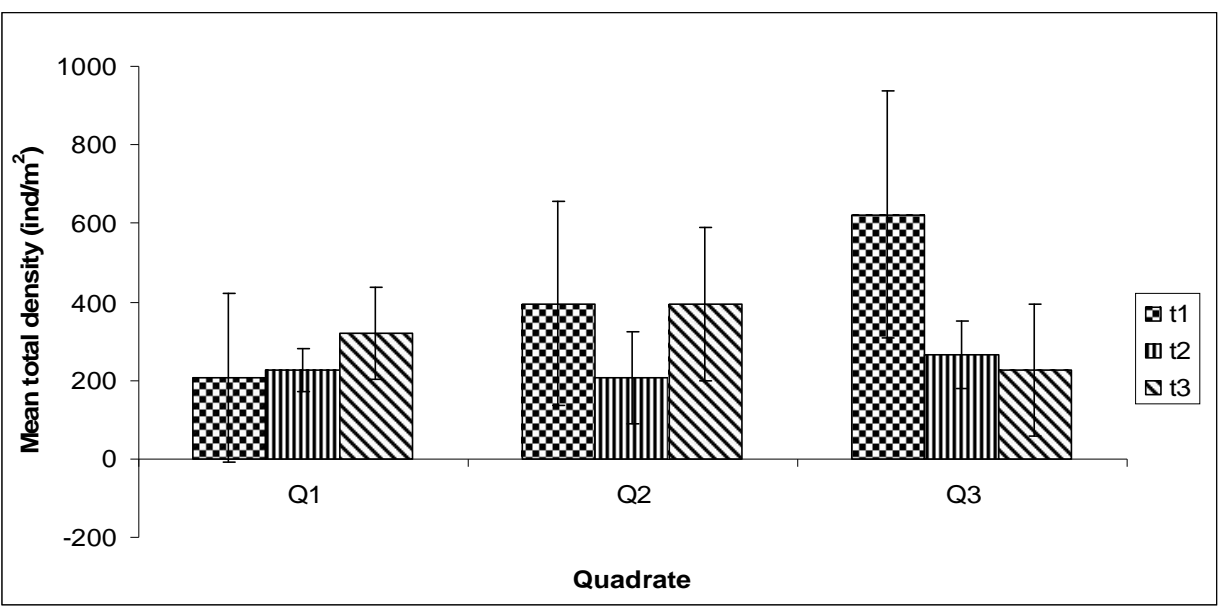

(b)

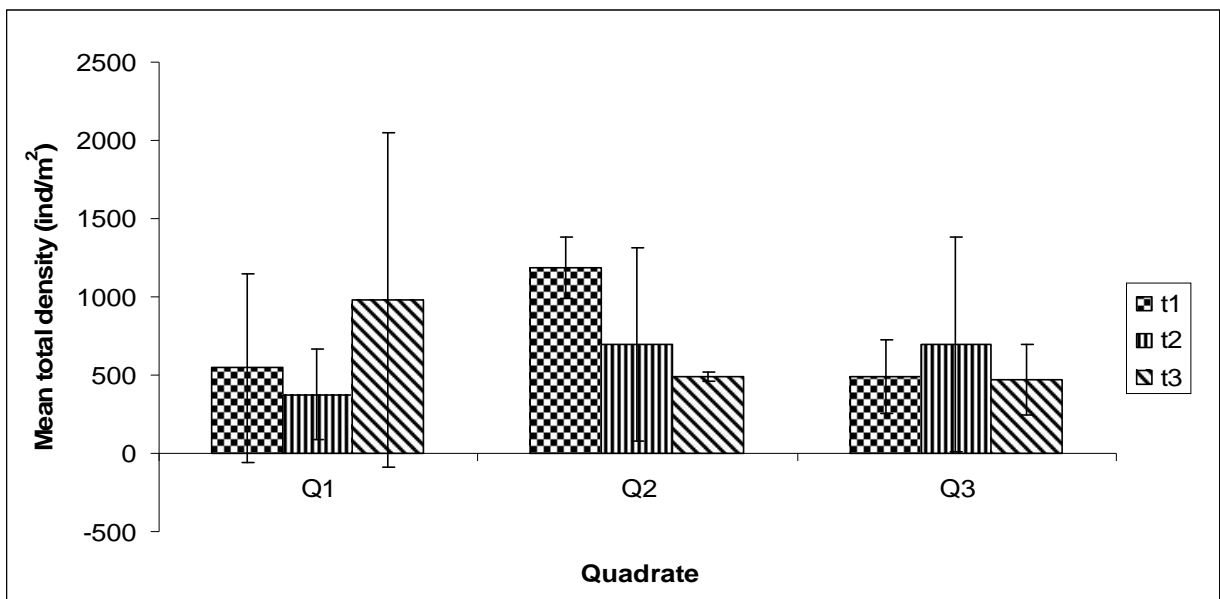

(c)

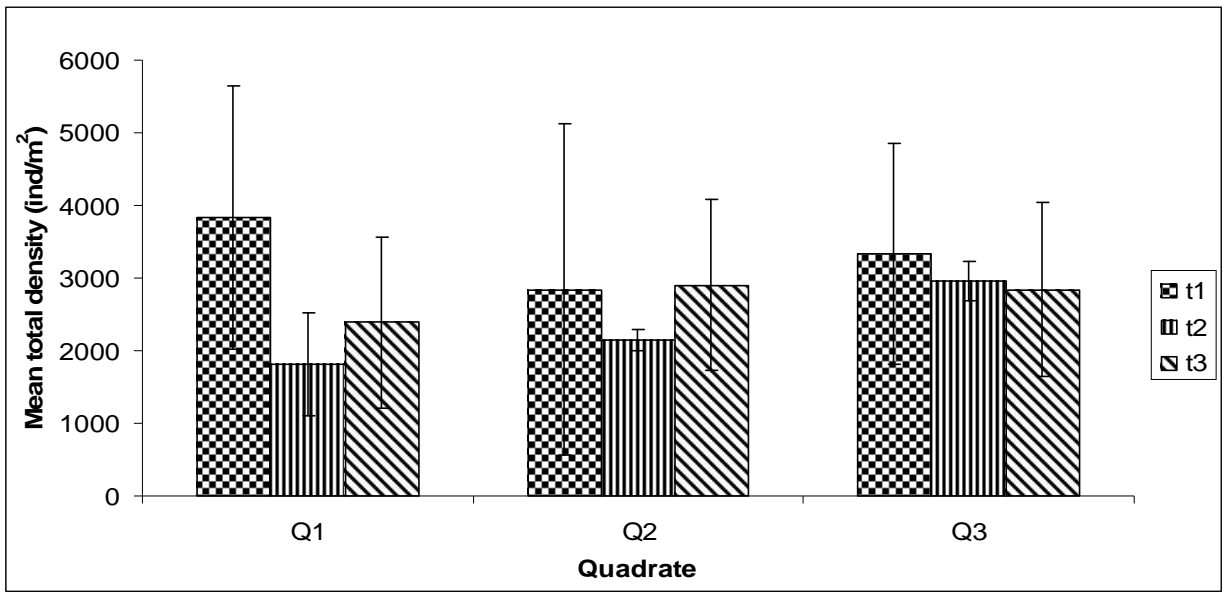

Figure 3.2. Mean density (ind. $/ \mathrm{m}^{2}$ ) of macrobenthos in (a) Sungai Duku (S1), (b) Tanjung Adang (S2), and (c) Merambong (S3).Note: $\mathrm{T}=$ transect 
Dominant group of macrobenthos

(a)

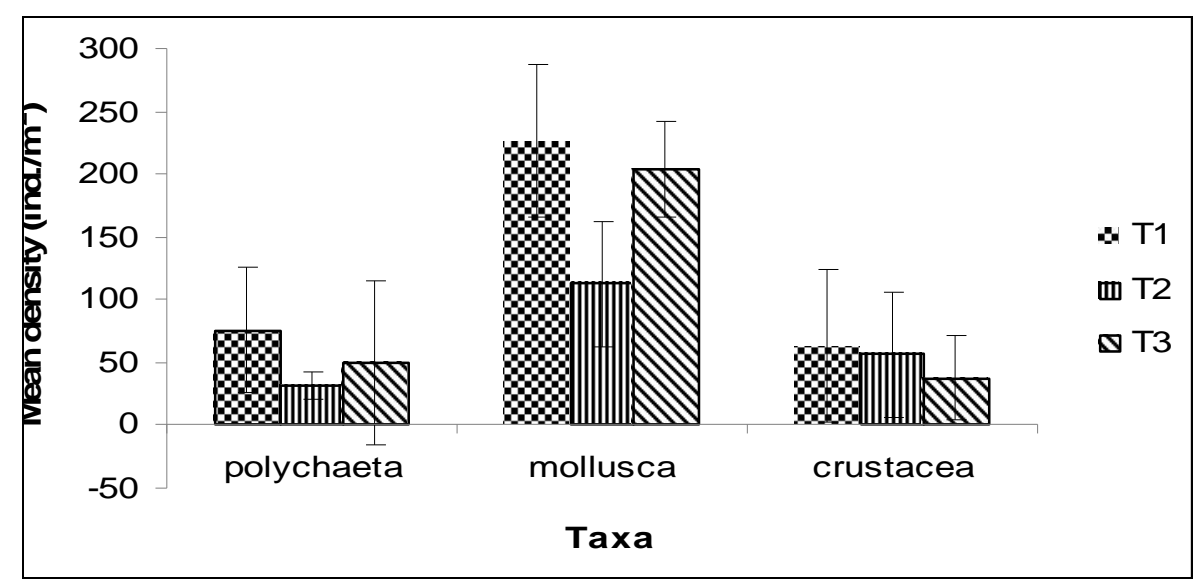

(b)

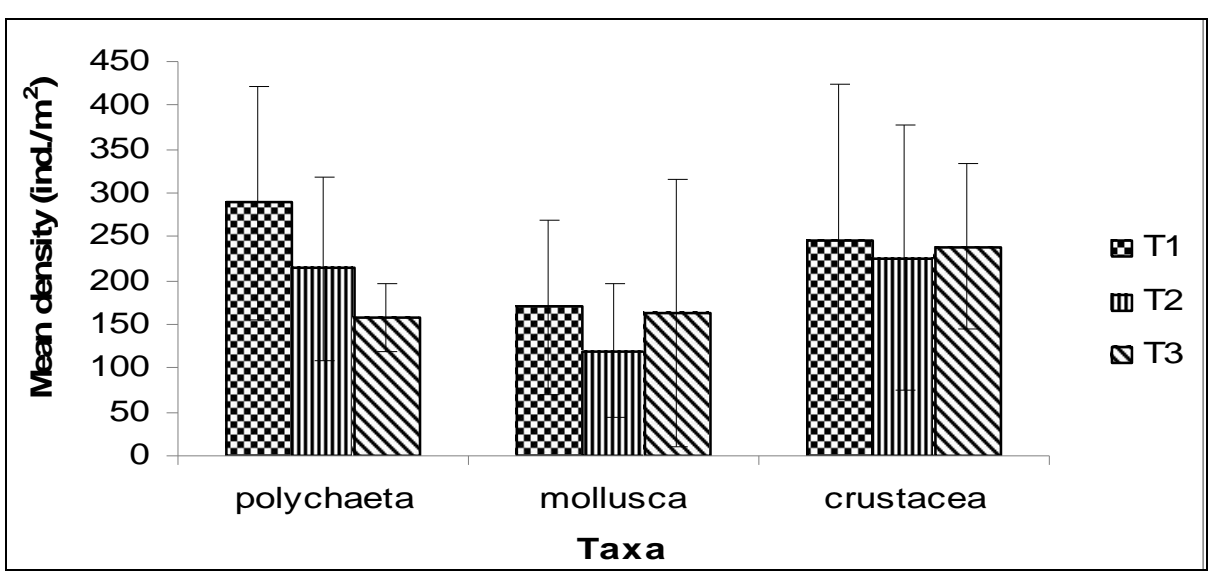

(c)

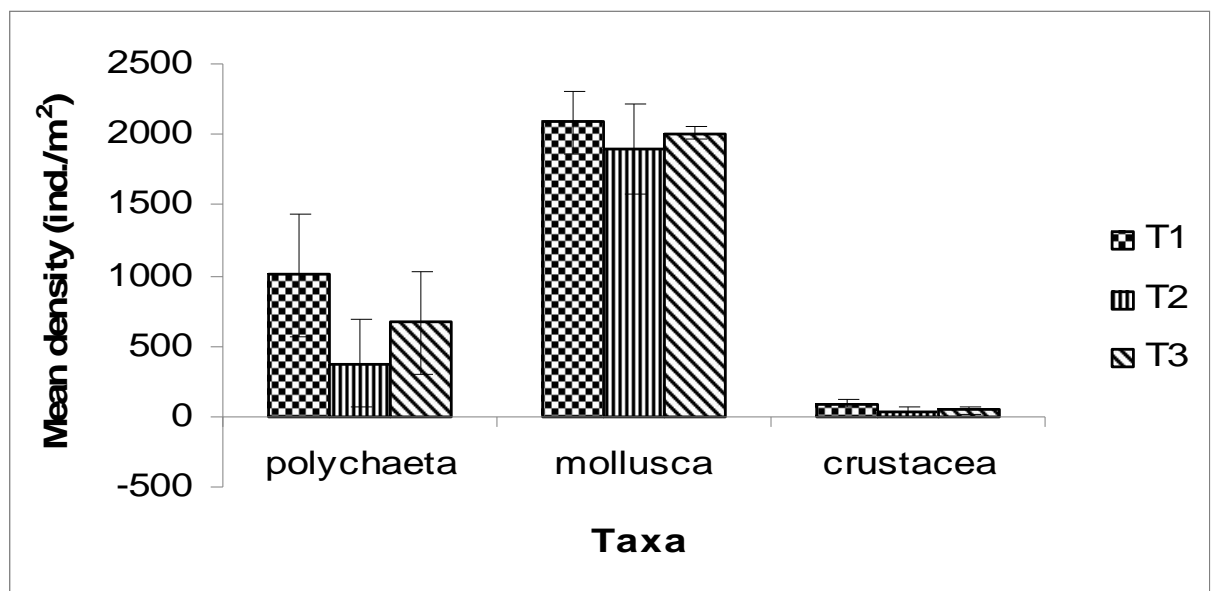

Figure 3.3. Mean density (ind. $/ \mathrm{m}^{2}$ ) of dominant groups of macrobenthos in (a) Sungai Duku (S1), (b) Tanjung Adang (S2), and (c) Merambong (S3). Note: T= transect 
Polychaetes, mollusks and crustaceans were observed to be the largest contributor to macrofaunal numbers in all stations in the seagrass beds of Sungai Pulai estuary (Figure 3.3). Mollusks (113 to 225 ind. $/ \mathrm{m}^{2}$ ) were the dominant group in Sungai Duku (S1) followed by polychaetes (31 to 75 ind.$/ \mathrm{m}^{2}$ ) and crustaceans (38 to 63 ind. $/ \mathrm{m}^{2}$ ). In Tanjung Adang (S2), these three groups were equally distributed with polychaetes (157 to 289 ind./ $\mathrm{m}^{2}$ ) being observed to be greater in number than crustaceans (226 to 245 ind. $/ \mathrm{m}^{2}$ ) and mollusks (119 to 169 ind. $/ \mathrm{m}^{2}$ ). Polychaetes (377 to 1004 ind./m²) and mollusks (1902 to 2084 ind. $/ \mathrm{m}^{2}$ ) were found in abundance in Merambong (S3) and the density of crustaceans was low (31 to $94 . / \mathrm{m}^{2}$ ).

\section{Polychaete community composition and diversity appologes}

13 families of polychaetes were observed in the seagrass bed of Sungai Pulai estuary and the numerically dominant families varied among stations (Figure 3.5). In Tanjung Adang (S2), the polychaete community was dominated by Nepthyidae (25\%) and Nereididae (24\%), followed by Glyceridae which represented $14 \%$ of the polychaetes. The composition of polycheates was dominated equally by Orbiniidae in Sungai Duku, S1 (25\%) and Merambong, S3 (24\%). Nereididae (20\%) was recorded as the second dominant polychaetes in Sungai Duku (S1) after Orbiniidae.

The diversity, richness and evenness index was relatively poor in Sungai Duku (S1) which is located at the upper stream with the lowest salinity compared to the other two stations located in closer proximity to the sea (Table 3.5). Merambong (S3) had the highest diversity index with a value of 1.94 indicating high diversity of polychaete species in the area. The composition of polychaetes differed significantly among stations (ANOSIM, R = 0.41, P: 0.001). Cluster analysis of Bray-Curtis similarities (Figure 3.5) and MDS analysis showed two groups of polychaetes with > $60 \%$ similarity. Polychaete community of Merambong (S3) clearly separated from others which indicated the influence of marine water and seagrass vegetation towards the estuarine community.

Table 3.5. Diversity index (H'), richness index (d), and evenness index (J') of polychaete composition recorded in Sungai Duku, Tanjung Adang and Merambong.

\begin{tabular}{lccc}
\hline Index & Sungai Duku (SI) & Tanjung Adang (S2) & Merambong (S3) \\
\hline Diversity index (H') & 0.73 & 1.51 & 1.94 \\
Richness index (d) & 0.33 & 0.77 & 1.23 \\
Evenness index $\left(\mathrm{J}^{\prime}\right)$ & 0.62 & 0.92 & 0.91 \\
\hline
\end{tabular}




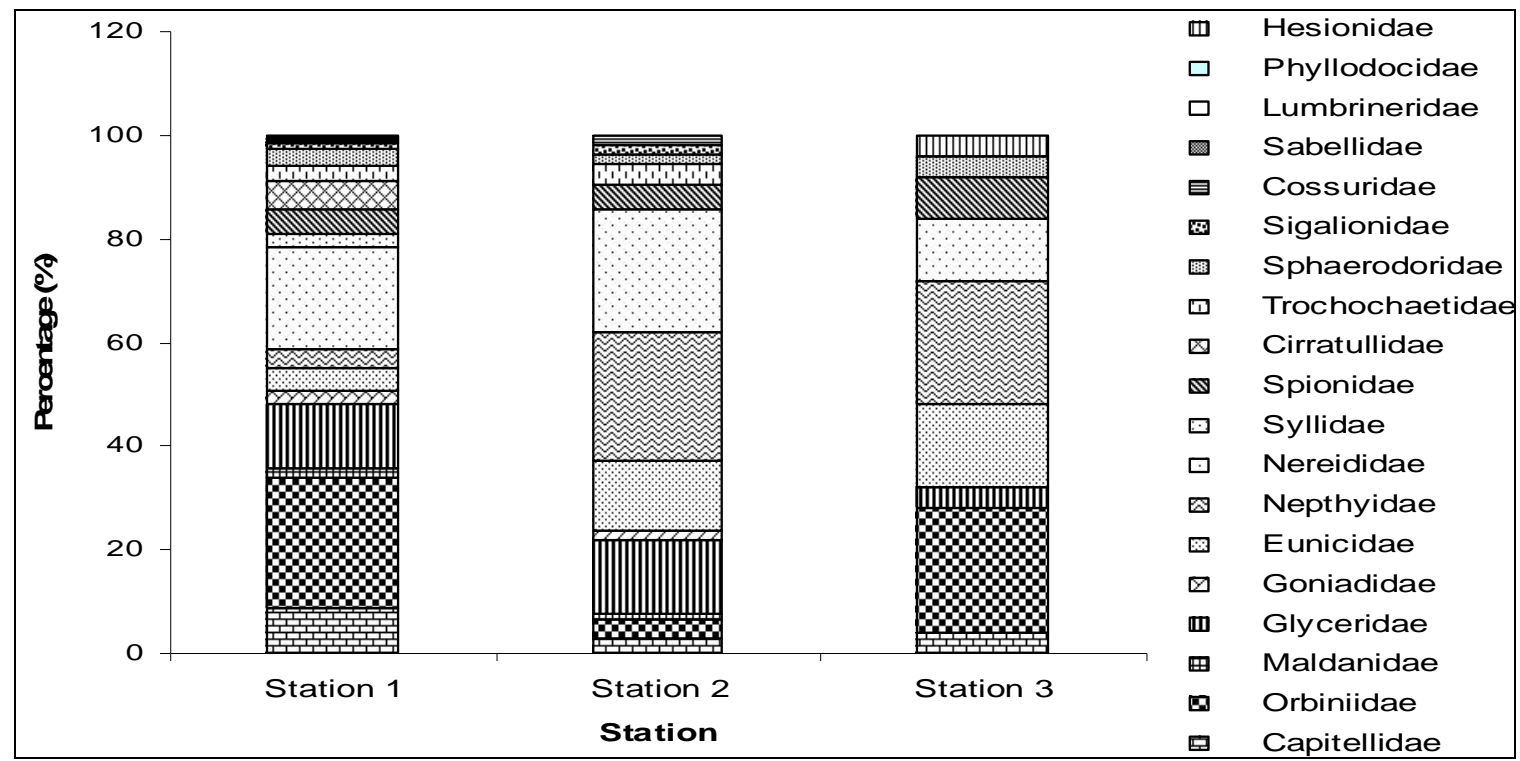

Figure 3.4. Composition of polychaetes in seagrass beds in Sungai Duku (S1), Tanjung Adang (S2) and Merambong (S3)
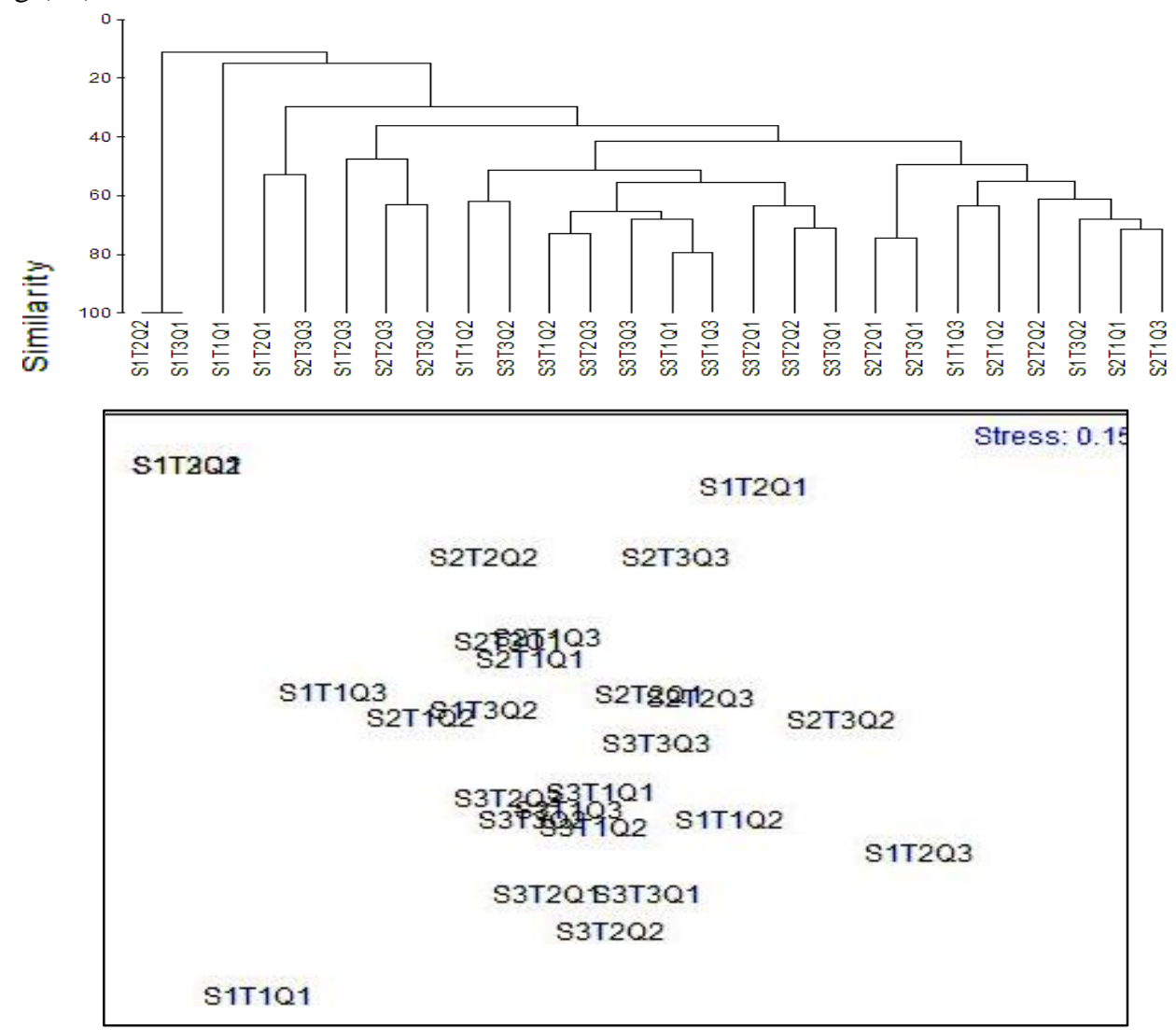

Figure 3.5. Cluster analysis dendrogram of Bray-Curtis similarity and MDS analyses for polychaetes composition in three sampling stations (Sungai Duku (S1), Tanjung Adang (S2) and Merambong (S3) in seagrass beds of Sungai Pulai estuary. 


\section{Divesity of benthos Meiobenthos}

Table 3.6. Diversity index ( $\left.H^{\prime}\right)$, richness index (d), and evenness index ( $\left.\mathrm{J}^{\prime}\right)$ of meiobenthos recorded in Sungai Duku, Tanjung Pelepas and Merambong.

\begin{tabular}{lccc}
\hline Index & Sungai Duku (S1) & Tanjung Adang (S2) & Merambong (S3) \\
\hline Diversity index (H') & 1.14 & 1.69 & 1.27 \\
Richness index (d) & 0.41 & 0.85 & 0.85 \\
Evenness index (J') & 0.66 & 0.67 & 0.50 \\
\hline
\end{tabular}

The status of benthic community diversity in the study area was determined using the Diversity index (H') Shannon Wiener, Richness index (d), and Evenness index ( $\mathrm{J}$ '). The diversity index $\left(\mathrm{H}^{\prime}\right)$ of each station (Table 3.6) showed a high value $\left(\mathrm{H}^{\prime}>1.0\right)$. Sungai Duku $(\mathrm{S} 1)\left(\mathrm{H}^{\prime}=1.14\right)$ showed the lowest value followed by Merambong $\left(\mathrm{H}^{\prime}=\right.$ 1.27) Tanjung Adang (S2) had the highest value of diversity index at 1.69. At Tanjung Adang (S2), the richness index (d) was highest when compared to other stations. It was observed that Tanjung Adang (S2) a high number of species. However, in Sungai Duku (S1) the species diversity showed a low number of meiobenthos species inhabiting the area. For the evenness index (J'), the values were high and showed similarity between Sungai Duku (S1) and Tanjung Adang (S2). But Merambong (S3) showed a lower value of evenness.

\section{Macrobenthos}

Table 3.7. Diversity index ( $\left.\mathrm{H}^{\prime}\right)$, richness index (d), and evenness index $\left(\mathrm{J}^{\prime}\right)$ of macrobenthos recorded in Sungai Duku, Tanjung Pelepas and Merambong.

\begin{tabular}{lccc}
\hline Index & Sungai Duku (S1) & Tanjung Adang (S2) & Merambong (S3) \\
\hline Diversity index (H') & 1.39 & 2.06 & 1.42 \\
Richness index (d) & 0.84 & 1.50 & 1.67 \\
Evenness index (J') & 0.83 & 0.88 & 0.53 \\
\hline
\end{tabular}

Overall, the sampling sites showed a high diversity ( $\mathrm{H}^{\prime}>1$ ) of macrobenthos during the sampling period (Table 3.7). The highest diversity index was found in Tanjung Adang (S2) $\left(\mathrm{H}^{\prime}=\right.$ 2.06), followed by Merambong (S3) and Sungai Duku (S3). High diversity values showed that macrobenthos in Tanjung Adang (S2) contained a high variety of species compared to the other stations. Merambong (S3) was found to have the highest richness index $(\mathrm{d}=1.67)$ among stations which means that the total number of species recorded was higher in this station, but with the lowest evenness index $\left(\mathrm{J}^{\prime}=0.53\right)$ showing that the individuals in this area have low distributional equitably among different species.

\section{Similarity analysis}

The similarity analysis using the Bray-Curtis cluster analysis estimated similarities in community structure between the different stations for meiobenthic and macrobenthic fauna. The Bray-Curtis cluster analysis for meiobenthos (Figure 3.6) produced two major clusters. Community in S1 with a $71 \%$ similarity level dominates the first group (ANOSIM, R: -0.21, P: 0.78 ) while the other two communities, which are in S2 and S3, dominate the second group with a $75 \%$ similarity level indicating the possible similarity in environmental factors tolerance between both communities. The cluster analysis clearly distinguished the samples only from S2 aggregate amongst themselves without the 
presence of other site samples to form distinct groups with a $70 \%$ similarity level (ANOSIM, R: -0.11, P: 0.7). Most samples from S3 formed one cluster with a $80 \%$ similarity level which indicates the highest similarity among their samples compared to the other two stations similarity level (ANOSIM, R: 0.43, P: 0.01). The sampling station with the different abiotic factors could give major influence in clustering meiobenthos into distinct groupings (ANOSIM, R: 0.783, P: 0.1)

Cluster analysis of macrobenthic community (Figure. 3.7) showed three distinct benthic community groupings (at $45 \%$ similarity) that apparently characterized by an assemblage of species different from one another (ANOSIM, R: 0.857, P: 0.1\%). Group-1 representing the Sungai Duku (S1) with a $45 \%$ similarity level (ANOSIM, R: -0.19, P: 0.8). The other two groups, were Tanjung Adang (S2) with 7 samples from station S2 forming a 50\% similarity level (ANOSIM, R: 0.19, P: 0.87), and Merambong (S3) formed one cluster with a $56 \%$ similarity which indicates the highest similarity among their samples compared to the other stations.
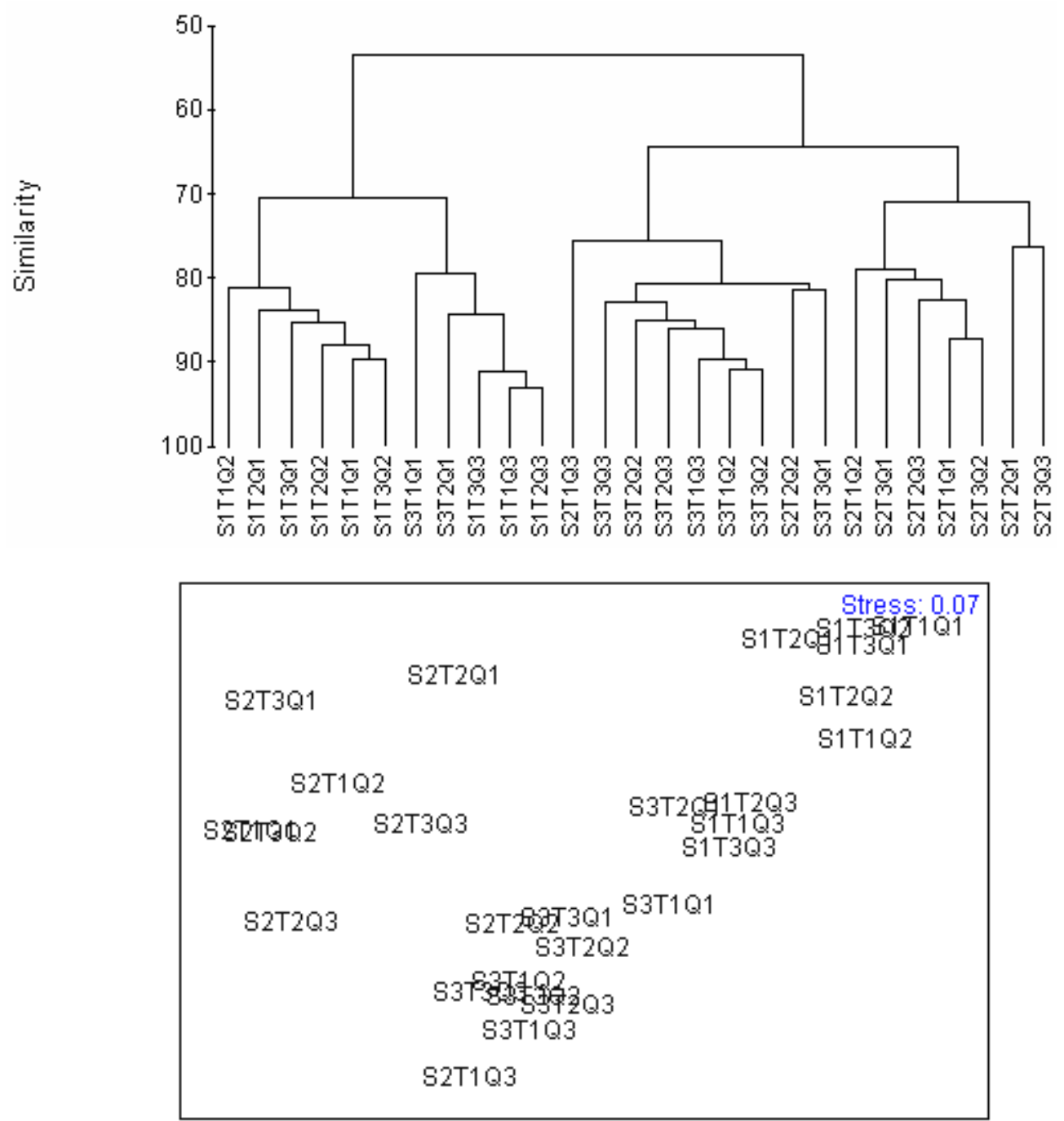

Figure 3.6. Cluster analysis dendrogram of Bray-Curtis similarity and MDS analyses for meiobenthos in three sampling stations (Sungai Duku (S1), Tanjung Adang (S2) and Merambong (S3) in seagrass beds of Sungai Pulai estuary. 


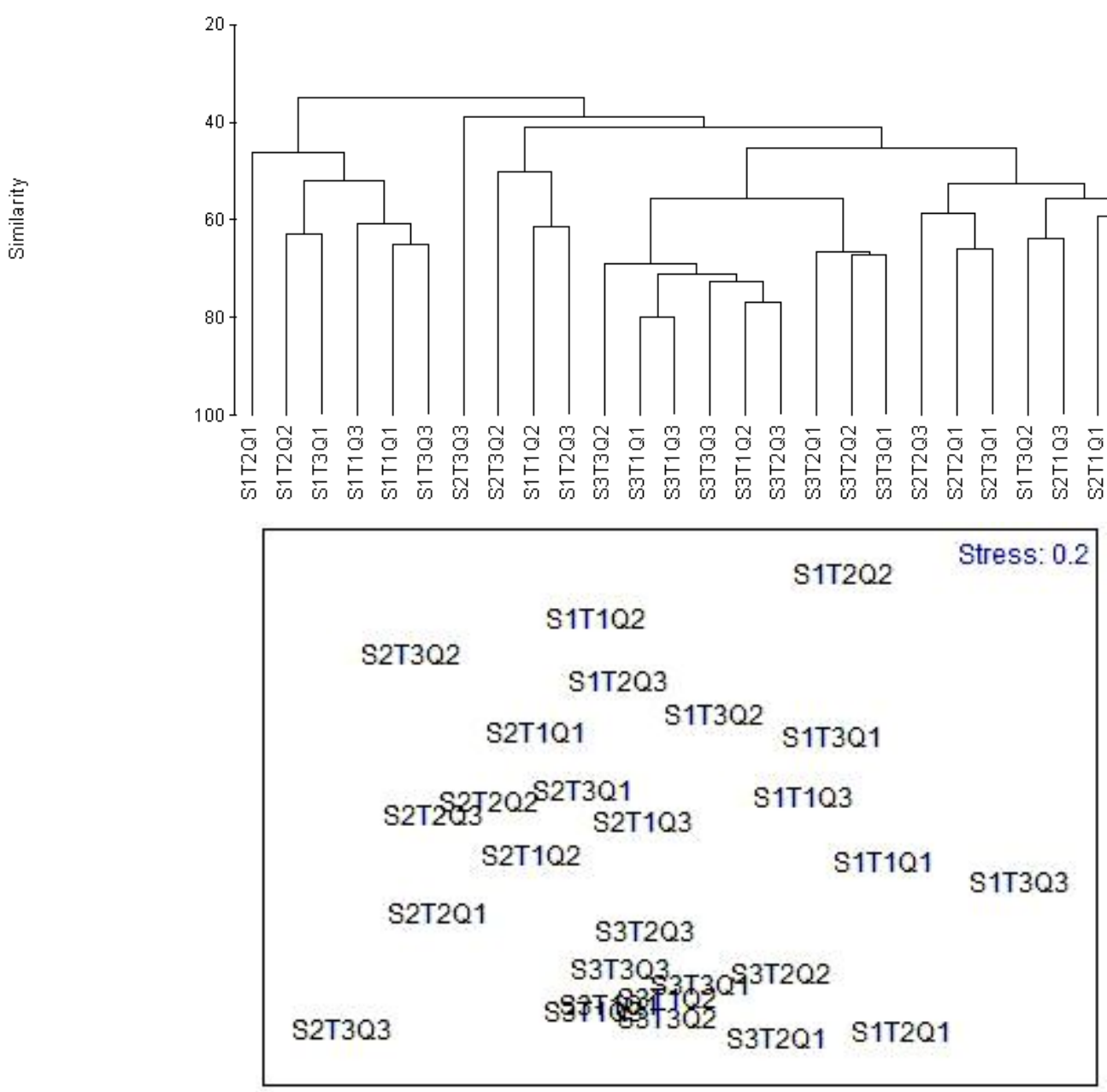

Figure 3.7. Cluster analysis dendrogram of Bray-Curtis similarity and MDS analyses for macrobenthos in three sampling stations (Sungai Duku (S1), Tanjung Adang (S2) and Merambong (S3) in seagrass beds of Sungai Pulai estuary.

\section{DISCUSSION}

There are several reasons that can be attributed to the value variety in terms of distribution, abundance and diversity of benthic fauna associated with seagrass beds. According to [29], the seagrass fauna are rarely associated with particular seagrass species but respond to a restricted set of physical environmental parameters. The abundance and composition are determined by physical factors such as temperature, salinity, turbidity, oxygen concentration and water movement, rather than the seagrass species on which the animals live [30]. Moreover, seagrass habitats which undergo extreme environmental changes generally report a low species richness value [31]. These could possibly explain the different abundance and distribution patterns of fauna recorded at each station.

Nematodes and harpacticoid copepods were the meiobenthic group found in abundance in all stations. Nematodes and harpacticoid copepods comprised more than $95 \%$ of the meiofauna in most sediment are already known as the most numerically abundant taxa in all environments [32]. [20] listed a total of 95 species of invertebrates from the water column, surface and 
in the sediments of seagrass bed located off the coastline of Tanjung Pelepas, Johor were observed.

A majority of the organisms were crustaceans, chaetognaths, echinoderms, molluscs and polychaetes. As recorded by [33], polychaete worms, mollusks and crustaceans are the dominant macrofaunal groups in all marine sediments. Crustaceans, molluscs and polycheates respectively formed the majority of the benthic epifauna and infauna in seagrass areas of the sampling stations, but chaetognaths and echinoderms were poorly recorded in the present study. A total of 24 different families of polychaetes containing more than 50 species were gathered in previous study [20]. Some of the common families were Arabellidae, Eunicidae, Glyceridae, Nepthyidae, Nereididae, Phyllodocidae and Spionidae. However, only four instead of seven families were found to dominate the seagrass beds during the current study, (Nereididae, Nepthyidae, Eunicidae and Glyceridae). Orbiniidae which was not reported in the literature was observed to be a dominate species in the sampling stations in the present study. Orbiniidae was reported to be spread widely on the seagrass bed, followed by Capitellidae, Spionidae and Lumbrineridae [34].

The low salinity encountered in Sungai Duku (S1) was due to the spatial location of Sungai Duku (S1). Located at the upper stream, the salinity decreased as this station was far from the sea. Benthic communities in the inner estuarine areas are very low in densities due to the low salinity [35]. Species diversity of meiobenthos on mudflat of the estuary also decreased as salinity declined due to osmotic stress. In addition, the muddy substrate of the sediment which was associated with mangrove in this station offer less space for benthic organisms to inhabit the area. According to [36] the finer the grain size, the lesser the space available and the lesser benthos inhabit the area, and conversely, the coarser the sediment grain size, the greater the space available, and the larger number of benthos inhabit the area. Meanwhile, in Tanjung Adang (S2) and Merambong (S3), the mean total density for both meiobenthos and macrobenthos were much higher when compared to Sungai Duku (S1) and might be due to the fine sand sediment. In addition, Merambong (S3) which is located in the area which exposed more to marine environment might have the advantage of more stable environment with high dissolved oxygen and low salinity fluctuations.

Seagrass beds or vegetated areas provide a physically stable environment for colonization by the benthic community [37][38]. Nevertheless, the present study indicates a moderate value of benthic faunal density and diversity which probably resulted from the recent industrial developments found in the area. It might also due to the location of the seagrass beds within the Sungai Pulai estuary, which is situated between extreme high and low tides causing physical variations within these areas. Thus, it may influence the distribution of meiobenthic and macrobenthic fauna. The salinity changes, which create stress, could be the major factor in reducing benthic communities in the intertidal estuary. According to [39] species diversity of benthos in some tropical estuaries is lower than in temperate because of drastic seasonal fluctuations in the environment. Besides, meiofaunal organisms are unevenly distributed horizontally, even when the sediment grain distribution is homogeneous and such unevenness can be caused by several factors [40]. The long exposure of the area to the lowest tide during the sampling session might cause some bias on the benthos data collected.

It can be concluded that the seagrass beds of Tanjung Adang (S2) was found to have the highest mean total density of meiobenthos of the seagrass beds within the Sungai Pulai estuary, followed by Merambong (S3) and Sungai Duku (S1) was found to have the lowest mean total density of meiobenthos. Meanwhile for the macrobenthic community, the seagrass bed of Merambong (S3) recorded the highest density. The differences in the benthic community in the seagrass bed of Sungai Pulai estuary are correlated with the different environmental setting and location within each station.

\section{ACKNOWLEDGEMENTS}

The authors are very grateful to the Ministry of Science, Technology and Environment (MOSTE 2005) for the financial supports during IRPA grant: Benthos Benthos Study of Malaysian South China Sea in which research study was carried out. 


\section{REFERENCES}

1. Kingston, P. F. 2001. Benthic Organism Overview. Pp. 286 - 291 in John H. Steel, Steve, A. Thorpe, Karpe K. Turekian (eds.). Encyclopedia of Ocean Sciences.Academic Press. Vol 1. 621 p.

2. Campbell, N. A. and Reece, J. B. 2002. International Edition Biology $6^{\text {th }}$ Edition. Pearson Education, Inc. San Francisco.

3. Jochem, F. J. 2005. The Zoobenthos [online]. http://www.jochemnet.de/ [Accessed 6 Aug. 2006]

4. Hall, G.S. 1996. Methods for the Examinations of Organismal Diversity in Soils and Sediments, Chapter 15, Meiofauna in Marine and Freshwater Sediments. Pp 187-195.

5. Schratzberger, M., Daneil, F., Wall, C.M., Killbride, R., Macnaughton, S.J., Boyd, S.E. Rees, H.L., Lee, K., Swannell, R.P.J. 2003. Response of estuarine meio- and macrofauna to in situ bioremediation of oil-contaminated sediment. Marine Pollution Bulletin. 46: 430443.

6. Mare, M.F., 1942. A study of a marine benthic community with special reference to the microorganisms. Journal of the Marine Biological Association of the United Kingdom 25: 517-554.

7. Thurman, H. V., Trujillo, A. P. 2002. Essentials of Oceanography. Prentice - Hall, Inc.Upper Saddle River, New Jersey. 524pp.

8. Pohle, G., Frost, B., Findlay, R. 2001. Assessment or regional benthic impact of salmon mariculture within the Letang Inlet, Bay of Fundy. Journal of Marine Science 58:417-426.

9. Mirto, S., Rosa, T.L., Gambi, C., Danovaro, Mazolla., R. A. 2002. Nematode community response to fish-farm in the Western Mediterranean. Journal of Environmental Pollution 116: 203-214.

10. Gee, J.M., 1989. An ecological and economic review of meiofauna as food for fish. Zoological Journal of Linneus Society 96:243$261 \mathrm{p}$.

11. Ali, A., Razak, S.A., Ibrahim, J., and Mohammad, M.I. 2002. Distribution of macrobenthos in the coastal waters of the east coast of Peninsular Malaysia. Marine Fishery Resource Development and Management Department, Chendering, South East Asean
Fishery Development Centre (SEAFDEC), Terengganu.

12. Heck, K. L., Able, K., Roman, C., and Fahay, M. 1995 Composition, abundance, biomass and production of macrofauna in a New England estuary: comparison among eelgrass meadows and other nursery habitats. Estuaries 18:379-389.

13. Little, C., 2000. The biology of soft shores and estuaries. Biology of habitats. Oxford University Press.

14. Lewis, F.G., Stoner, A.W., 1983. Distribution of macrofauna within seagrass beds: an explanation for patterns of abundance. Bull. Mar. Sci. 33: 296-304.

15. Lewis III, F.G., 1984. Distribution of macrobenthic crustaceans associated with Thalassia, Halodule and bare sand substrata. Mar. Ecol. Prog. Ser. 19: 101-113.

16. Ansari, Z.A., and Parulekar, A.H., 1993. Environmental stability and seasonality of a harpacticoid copepod community. Marine Biology, 115: 279-286.

17. Sasekumar A., Leh, C.M.U., Chong, V.C., Rebecca, D., and Audery, M.L. 1989. The Sungai Pulai (Johor): A unique mangrove for marine sciences in the 90's. Eds S.M.Phang, A. Sasekumar and S. Vickineswary. Pp 191-211. Institute forAdvanced Studies, University of Malaya, Kuala Lumpur.

18. Troch, M.D., Gurdebeke, S., Fiers, F., Vincx, M., 2001. Zonation and Structuring factors of meiofauna communities in a tropical seagrass bed (Gazi Bay, Kenya). Journal of Sea Research, 45: 45-61

19. Arshad, A., Siti Sarah, M.Y., and Japar, S.B. 1994. A comparative survey of the invertebrate fauna in seagrass and nonseagrass flats in Merambong shoal, Johor, Malaysia. In Proceedings, Third ASEANAustalian Symposium on Living Coastal Resources. 16-20 May 1994.Chulalongkorn University, Bangkok, Thailand.

20. Monthum, Y., and Aryuthaka, C. 2006. Spatial distribution of meiobenthic community in Tha Len seagrass bed, Krabi Province, Thailand. Coastal Marine Science 30(1):146-153.

21. McIntyre, A.D., and R.M. Warwick, 1984. Meiofauna Techniques. Pages 217-244 in A.D. McIntyre, and N.A. Holme, editors, Methods for the Study of Marine Brnthos. IBP 
Handbook 16 Oxford: Blackwell Scientific Publications.

22. Higgins, R.P., and Thiel, H. 1988. Introduction to the Study of Meiofauna.

23. Day, J. H. 1967. A Monograph of the Polychaetes of Southen Africa; 1 Erantia; 2 Sedentaria. British Natural History Museum, London.

24. Fauchald, K., Jumars, P.A., 1979. The Diet of Worms: A Study of Polychaete Feeding Guilds. Oceanography and Marine Biology Annual Review 17: 193-284.

25. Holdich, D.M., Jones, J.A., 1983. Tanaids Keys and Notes for the Identification of Species. In: Kermack, D.M., Barnes, R.S.K. (Eds.), Synopsis of the British Fauna, vol. 27. Cambridge University Press, Cambridge, 98 pp.

26. Buchanan, J.B., 1984. Sediment analysis. Pp 41-65 in: N.A.Holme and A.D. McIntyre (eds.). Methods for the of marine benthos. Blackwell Scientific Publication.London, U.K. $387 \mathrm{p}$.

27. Clarke, K.R., and Warwick, W.M. 2001., Changes in Marine Communities: An Apporoach to Statistic Analysis and Interpretation, $2^{\text {nd }}$ ed. PRIMER-E, Plymouth $144 \mathrm{p}$

28. Howard, R.K., Edgar, G.J., Hutchings, P.A., 1989. Faunal assemblages of seagrass beds. In: Larkum, A.W.D., McComb, A.J., Sheperd, S.A.ŽEds.., Biology of Seagrasses A Treatise on the Biology of Seagrasses with Special Reference to the Australian Region. Elsevier, The Netherlands, pp. 536-564.

29. Edgar, G.J., 1990. The Influence of Plant Structure on the Species Richness, Biomass and Secondary Production of Macrofaunal Assemblages Associated with Western Australian Seagrass Beds. J. Exp. Mar. Biol. Ecol. 137: 215-240.

30. Jackson, J.B.C., 1972. The Ecology of the Molluscs; the Thalassia Communities, Jamaica, West Indies: II. Molluscan Population Variability along an Environmental Sress Gradient. Mar. Biol. 14: 304-377.

31. Vincx, M., 1996. Meiofauna in marine and freshwater sediments Pp. 187-195 in G.S. Hall, ed. Methods for the examination of organismal diversity in soils and sediments.

32. Mackie, A.S.Y., and Oliver, P.G. 1996. Marine macrofauna: Polychaetes, Molluscs and Crustaceans. Pp. 263-277 in G.S. Hall ed. Methods for the examination of organismal diversity in soils and sediments.

33. Christopher, R.S, Bario, F., Hawkin, L.E., Aryuthaka, C., Nimsantijaroen, S., Kendall, M.A., Paterson, G.L.J. 2005. Patterns of polychaetes communities in tropical sedimentary habitat: A case study in SouthWesternn Thailand. The Raffles Buletin of Zoology 2005 53(1): 1-11.

34. Elliot, M., and Kingston, P.E., 1987. The sublittoral benthic fauna of the estuary and Firth of Forth, Scotland. Proceedings of the Royal Society of Edinburgh, 93B: 449-465.

35. Nybakken, J.W., 2001. Marine biology. An ecological approach. Fifth edition.

36. Bell, S.S., and Sherman, K.M., 1980. A field investigation of meiofaunal dispersal: tidal resuspension and implications. Marine Ecology- Progress Series 3: 245-249.

37. Palmer, M.A., 1986. Hydrodynamics and structure: interactive effects on meiofauna dispersal. Journal of Experimental Marine Biology and Ecology, 104: 53-68.

38. Alongi, D.M., (1990). The ecology of tropical soft-bottom benthic ecosystems. Oceanography and Marine Biology: An Annual Review, 28: 381-496.

39. Flach, E., Muthumbi, A., and Heip, C. 2002. Meiofauna and macrofauna community structure in relation to sediment composition at the Iberian margin compared to the Goban Spur (NE Atlantic). Progress in Oceanography. 52:433-457. 
Malaysian Journal of Science 28 (2): 143- 159 (2009) 